\title{
Assessing authenticity of nineteenth-century shopping passages
}

\author{
Bie Plevoets and Koenraad Van Cleempoel \\ PHL University College \& Hasselt University, Diepenbeek, Belgium
}

\begin{abstract}
Purpose - The purpose of this paper is to explore the conservation and contemporary management of three nineteenth-century shopping passages: the Galleries Saint-Hubert in Brussels, the Galleria Vittorio Emanuele II in Milan and the Passage in The Hague. The submission of the Galleries SaintHubert to the World Heritage Tentative List in 2008, presents a unique opportunity for studying this typology in its contemporary environment.

Design/methodology/approach - The authors' research questions are: what are the characteristics of passages? what are their authentic values? and how can the authenticity of these buildings be conserved by their contemporary management? The applied methodology is a cross-case-comparison, based on the definition of authenticity as presented in the Nara Document on Authenticity. The analysis is presented in the form of a matrix.

Findings - The findings show that the significant value of passages does not only include the architecture of the building but also the versatility of its program and its present urban role. It is only by conserving this combination that these buildings can be conserved in their full richness of authenticity.

Practical implications - Criteria for transnational inclusion in the World Heritage List of several nineteenth-century passages are suggested as the matrix used for cross-case-comparison may be applied to analyse other case studies of passages, as well as for other types of heritage where authenticity of the site is threatened by uncontrolled retail development.

Originality/value - Although passages have been studied extensively within the field of architectural history, retail history and socio-cultural studies, hardly any previous research had focused on the preservation and contemporary management of this building type.
\end{abstract}

Keywords Belgium, Italy, The Hague, Shopping centres, Building conservation, Conservation, Passage, Authenticity, World Heritage, Adaptive reuse

Paper type Research paper

\section{Introduction}

Since their development by the turn of the nineteenth century, passages have been an important subject of study in the field of architectural history (Pevsner, 1976; Geist, 1979), retail history (Davis, 1966; Kooijman, 1999; Miellet, 2001; Mesher, 2010) and socio-cultural studies (Benjamin, 1969 [1935]; Vanderburgh and Du Four, 1999; Benjamin et al., 2002 [1932]), but limited scholarly studies have focussed on its preservation and contemporary management (an exception is MacKeith, 1986). However, the few remaining passages show that their restoration and rehabilitation is often essentially commercially driven and does not fully respond to the authentic value of the site.

In 2008, the Galleries Saint-Hubert in Brussels was submitted to the UNESCO World Heritage Tentative List (UNESCO, 2008b). The application form stressed that the addition to the list should not be restricted to the passage in Brussels but that other

The authors would like to thank the reviewers for their constructive comments. This research was funded by a PhD grant of the Institute for the Promotion of Innovation through Science and Technology in Flanders (IWT-Vlaanderen). 
JCHMSD

1,2

\section{6}

transnational examples should be included. The renewed attention for passages in the context of UNESCO World Heritage creates an opportunity for studying this typology in its contemporary environment.

Through case study analyses we explored the tension between the conservation of passages as heritage sites and their contemporary management. The research questions are:

$R Q 1$. What are the characteristics of passages?

RQ2. What are their authentic values?

RQ3. How can the authenticity of these buildings be conserved by their contemporary management?

First, we describe the characteristics of the passage as a building type. Second, we explore the meaning of authenticity as a criterion for World Heritage listing. Third, a cross-case comparison is made between three passages: the Galleries Saint-Hubert in Brussels (1846-1847), the Galleria Vittorio Emanuele II in Milan (1865-1877) and the Passage in The Hague (1883-1885).

\section{Origin and development of the passage as a building type}

By the end of the eighteenth century, store design became part of ever increasing architectural typologies (Pevsner, 1976), among which the passage Beside "passage," the building type can be indicated with different terms, e.g. "arcade" or "gallery," which are more commonly used in English. As Geist (1979) explains in his extensive typological study, all these terms differ slightly in meaning. As this paper only deals with nineteenth century European examples, we further use the term "passage."

Among the first named example of a passage, is the Galeries de Bois (1788) in Paris, constructed out of wood and with shops on both sides under a covered gallery - the different streets a passage is composed of - offering luxury products from all over the world. It included not only shops but also bars, restaurants and gambling houses, which made it the outstanding meeting place for the French bourgeoisie. Following Galeries de Bois, passages were rapidly built all over Paris and soon in the whole of France and Europe. Chronologically, Geist (1979) divides the evolution of the type in six different periods but in general two main periods are defined: the early nineteenth century, which is seen as the phase of development, and the period after 1840, when passages became monumental (Lemoine, 1990; Royal Commission of Monuments and Sites of the Brussels Capital Region (RCMS), 1998; Kooijman, 1999).

The early passages (ca. 1788-ca. 1840) were rather small in terms of length and width, like alley-ways, and originated as passageways under a building or a group of buildings, protecting the pedestrians from the mud and dirt in the streets (Geist, 1979). The most innovative aspect, however, in the development of the passages of the early period was their role as a new retail concept. The display window became important for presentation; the former "oral salesmanship" was replaced by a "visual promotion." Additionally the passage became a place for recreation and strolling (Benjamin et al., 2002 [1932]). Their role in the urban fabric becoming more "theatrical" (Kooijman, 1999). A clear example is the Burlington Arcade (1818-1819) in London, one of the few early passages that has been preserved (see Plate 1 ). 


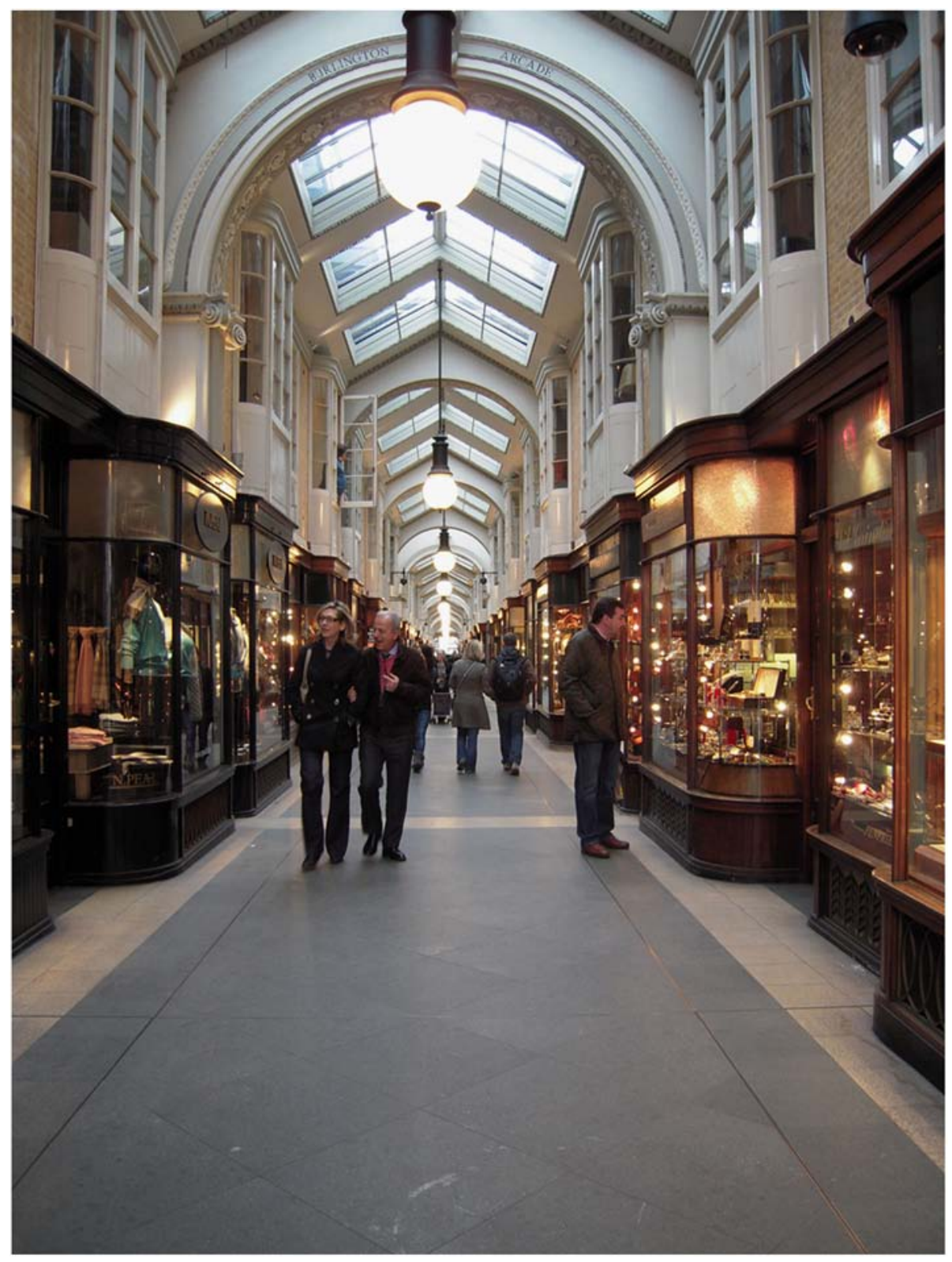

Shopping passages

During the second phase (ca. 1840-ca.1930), the passages became higher and wider. Shops were usually located on the ground floor, and two or more floors above these shops were used for dwellings; a theater or hotel was often added to the program. New materials such as glass and iron influenced its architecture. A cupola was 
JCHMSD

1,2

138 introduced in the center of the passage, at the intersection of two galleries. In line with contemporary fashion, the style was eclectic with neo-classical ornaments.

The transition between both phases is Gallery d'Orléans (1828-1829) in Paris, influencing many passages of the second half of the nineteenth century. Its spatial dimensions, arched glass roof and interior façades served as inspiration for other passages. The architect of the Galleries Saint-Hubert in Brussels, Jean-Pierre Cluysenaar (1811-1880), based his concept and program on Gallery d'Orléans (Conde Reis, 1998). This Galleries Saint-Hubert is the earliest example of a monumental passage. It can even be considered as its conceptual archetype: interior space becomes exterior. Consequently, Galleries Saint-Hubert inspired many later passages. Giuseppe Mengoni (1829-1877), architect of the Galleria Vittorio Emanuele II in Milan, consulted Cluysenaar in the 1860s (Geist, 1979). Another passage inspired by Brussels is the Passage in The Hague; although the initial design of the Passage represented an eclectic architectural style, the actual realization shows strong resemblance to the Galleries Saint-Hubert.

This brief historical survey provides the passage's essential characteristics:

(1) connection in the urban fabric for pedestrians combined with;

(2) an innovative retail concept, which became;

(3) an innovative architectural typology that could serve as a;

(4) political, cultural, social or economic symbol for the city providing; and

(5) a place for strolling and recreation containing a mix of activities.

\section{The notion of authenticity in relation to the World Heritage Status}

Authenticity is a layered concept that has been extensively discussed within the field of heritage conservation and beyond. When the first conservation theories became established in the nineteenth century, there was discussion between the Restoration movement, led by Eugène Emmanuel Viollet-le-Duc (1814-1879), and the Anti-restoration movement, led by John Ruskin (1819-1900) with authenticity at its heart. But the word itself was hardly ever mentioned in their writings.

The term authenticity was mentioned in the Charter of Venice (ICOMOS, 1964) in relation to esthetic and historic values. When in 1972 the World Heritage Convention was established, one of the criteria for inclusion in the World Heritage List was "the test of authenticity in design, materials, workmanship and setting" (UNESCO, 1977, article 9). Despite the aim of the World Heritage List to include "cultural and natural heritage around the world [...] of outstanding value to humanity" (UNESCO, 2010), there was imbalance in the distribution of listed properties between the continents, in favor of European, and more generally western heritage sites (Smith, 2006). In an attempt to compensate this imbalance, a more elaborate understanding needed to be formulated, particularly in its relationship toward scientific and technical development (Muñoz Viñas, 2005), traditional societies and cultural diversity (Jokilehto, 1999). The discussion, held at Nara in 1994, resulted in the so-called Nara Document on Authenticity (Larsen, 1995). From 2005 onwards, this is considered as a practical basis for examining authenticity of all cultural properties proposed for inclusion in the World Heritage List (Cameron, 2006; UNESCO, 2008a). 
It states that, when judging the authenticity of a particular site, both tangible and intangible expressions of heritage need to be considered (ICOMOS, 1994, article 7).

[Those] judgments may be linked to the worth of a great variety of sources of information. Aspects of the sources may include form and design, materials and substance, use and function, traditions and techniques, location and setting, and spirit and feeling, and other internal and external factors. The use of these sources permits elaboration of the specific artistic, historic, social, and scientific dimensions of the cultural heritage being examined (ICOMOS, 1994, article 13).

This, however, did not stop the discussion on the concept of authenticity. Heynen (2006) argued convincingly that Nara does not offer a clearly fixed meaning, but that its intended vagueness recognizes the underlying, but hard to define qualities of authenticity. Other authors questioned the authority of experts for claims and judgments on authenticity. They would rather pass this authority to the local community (Assi, 2000; Davison, 2008). This top-down relationship can also be found in the relationship between expert, heritage site and the visitor or user who is considered a passive consumer (Smith, 2006), even though the notion of authenticity seemed to be understood entirely different by tourists than it is traditionally defined by experts (Grayson and Martinec, 2004; Timothy and Boyd, 2003).

Despite its shortcomings, Nara's definition has been applied widely in assessing proposed World Heritage Sites, among others. It has been found useful within conservation practise for assessing, discussing and reporting on heritage values especially within an interdisciplinary context (Plevoets and Van Cleempoel, 2009; Starn, 2002; UNESCO, 2008a; Van Balen, 2008). As argued by Herb Stovel (2007), the concept of authenticity is of major importance in relation to World Heritage, not only for the nomination phase, but equally to ensure the quality of guidance provided to management and conservation treatment decisions subsequent to inscription. Stovel recognizes the complexity of the concept of authenticity but proposes to deconstruct and reassemble the concept to make it more understandable and easily to use in conservation analysis, for example by analyzing the relative authenticity of the various characteristics defined one by one.

Within the framework of World Heritage the tension between commercial exploitation of a site and preservation of its authenticity has been debated mainly in relation to cultural tourism (e.g. Pedersen, 2002). However, for sites with commercial uses - such as passages - the tension between retail development and authenticity is equally present. Jokilehto (1985) illustrated this tension with the example of the historic town of Lübeck which could not be accepted to the World Heritage List because too much of its fabric has been lost due to - among other reasons uncontrolled commercial development; English Heritage, English Historic Towns Forum, \& Planning Advisory Service (2005) have researched the tension between heritage and retail development in historic areas and formulated guidelines to balance both aspects.

But also on the level a single heritage building authenticity may be threatened due to retail activities on site. As the historic center is often also the commercial heart of a town, the possibility for new construction is limited and as such, retailers often locate their stores in existing (historic) buildings (Plevoets and Van Cleempoel, 2009). For some retailers, being located in a historic building even becomes a tool for differentiation toward competitors by offering their customers an "authentic 
JCHMSD

1,2 experience." The meaning of authenticity, however, is understood differently within the context of heritage conservation as in retail design; offering an authentic customer experience implies appealing to customers' senses, emotions and values with the aim to create personal, intuitive relationships with the specific brand or retailer. The offered "experience" may often be called "fake" or "hyperreal" as it seems to present an ideal historic setting to impress customers (Plevoets et al., 2010).

\section{Case studies}

\subsection{Methodology}

We have selected case studies through critical case selection which means they represent very clear examples of different possible approaches toward restoration, rehabilitation and site management of passages (Yin, 2009). However, to facilitate comparison we defined some common features:

(1) construction period being the second half of the nineteenth century;

(2) program;

(3) architectural concept;

(4) present role in urban fabric; and

(5) closely preserved to their original appearance.

For each case, data were collected on the history of the building, its restoration and contemporary management. Information on the history of the buildings was found in literature on passages in general (Geist, 1979) and in literature on the specific case studies (Flory and Paoli, 2003; Kooijman, 1999; Knibbeler, 1986; RCMS, 1998). For the Galleries Saint-Hubert, an extensive publication on the restoration was available (RCMS, 1998). There are no publications on the restoration of the Passage in The Hague, so the project was studied through archival research (Rijksarchief in Zeist - monument number 46627 - and city archive of The Hague - register numbers 0696-01 and 0708-01) and in-depth interviews with different stakeholders involved in the project (R. de Booij, personal communication, September 10, 2008; S. Tol, personal communication, March 10, 2009; M. van Wingerde, personal communication, August 18, 2008). Moreover, we made in situ observations of each case while documenting the current state of the building, the activities currently taking place and the particular stores located in each shop unit (Zeisel, 2006).

For each case study we first present a brief description of its history. Second, we give an evaluation of the authentic intrinsic - fixed, unchanged, universal values attributed to cultural heritage - and extrinsic values - values produced out of the interaction of a building or site and its context - of the building (Mason, 2002). Third, we describe how these values have been preserved or not by the contemporary restoration and management of the site.

Finally, there is a cross-case for which we deconstructed the concept of authenticity as proposed by Stovel. We used the six "aspects of authenticity" - called "attributes of authenticity" in the Operational Guidelines (UNESCO, 2008a, p. 22) - as described in article 13 of the Nara Document: form and design, materials and substance, use and function, traditions and techniques, location and setting and spirit and feeling. As these aspects are rather generic and not immediately related to the typology of the 
passages, we added subcategories for three aspects:

(1) Form and design:

- lighting;

- advertising; and

- store front.

(2) Materials and substance:

- ornaments and floors;

- polychromy;

- glass roof; and

- steel structure.

(3)
Spirit and feeling:
- scale of the stores;
- prestige of stores;
- quality of sold merchandises; and
- public.

Following ICOMOS' article 7, we also include tangible and intangible issues. These were placed in a matrix to achieve a detailed and holistic analysis of the three sites. Within each field we give a brief description of how the specific feature is treated, whenever possible we included a photograph to clarify the text. To each field we added a color coding to indicate if the particular intervention respects the authentic value or not. As such, the developed matrix allows to analyze each case in detail without overlooking certain aspects, presents possible discrepancy within the conservation and rehabilitation project and eases detailed comparison between the cases.

\subsection{The Galleries Saint-Hubert in Brussels}

History: The Galleries Saint-Hubert was constructed between 1846 and 1847, following a neoclassical design of architect Jean-Pierre Cluysenaar (1811-1880). The program was a well-designed combination of an official national monument expressing a new politic reality after the independence of Belgium in 1830, an urban design to solve traffic flows and a retail space (Conde Reis, 1998).

The Galleries Saint-Hubert is the earliest example of a monumental passage. It was also the first passage in history that was not financed by private investors, but with public funding instead (Geist, 1979). As such, the passage acquired a public and institutional character. Accordingly, the Galleries Saint-Hubert was the first passage to be considered as an urban project connecting existing streets (see Plates 2 and 3).

Notwithstanding some minor repairs, the Galleries Saint-Hubert had never been restored as a whole (Geist, 1979). But this happened in 1997, in honor of its 150th anniversary. The restoration was preceded by historic and scientific research, taking the richness of the initial program as a basis for the restoration concept (RCMS, 1998).

Value assessment: The most important intrinsic values of the Galleries Saint-Hubert are its historic and architectural significance as it was the first real example of a monumental passage; also the buildings' program combining retail, culture, leisure and dwelling was unique at its time. As to the extrinsic values, the Galleries SaintHubert has been extremely well conserved as hardly any alterations have been made to the building over its 150 years of existence.

Conservation and management: On the one hand, the conservation project focussed on the restoration of the material evidence. Preliminary to the restoration an inventory 


\section{JCHMSD \\ 1,2}

142

Plate 2.

Lithography of Cannelle, ca. 1850 (Archive of Brussels city)

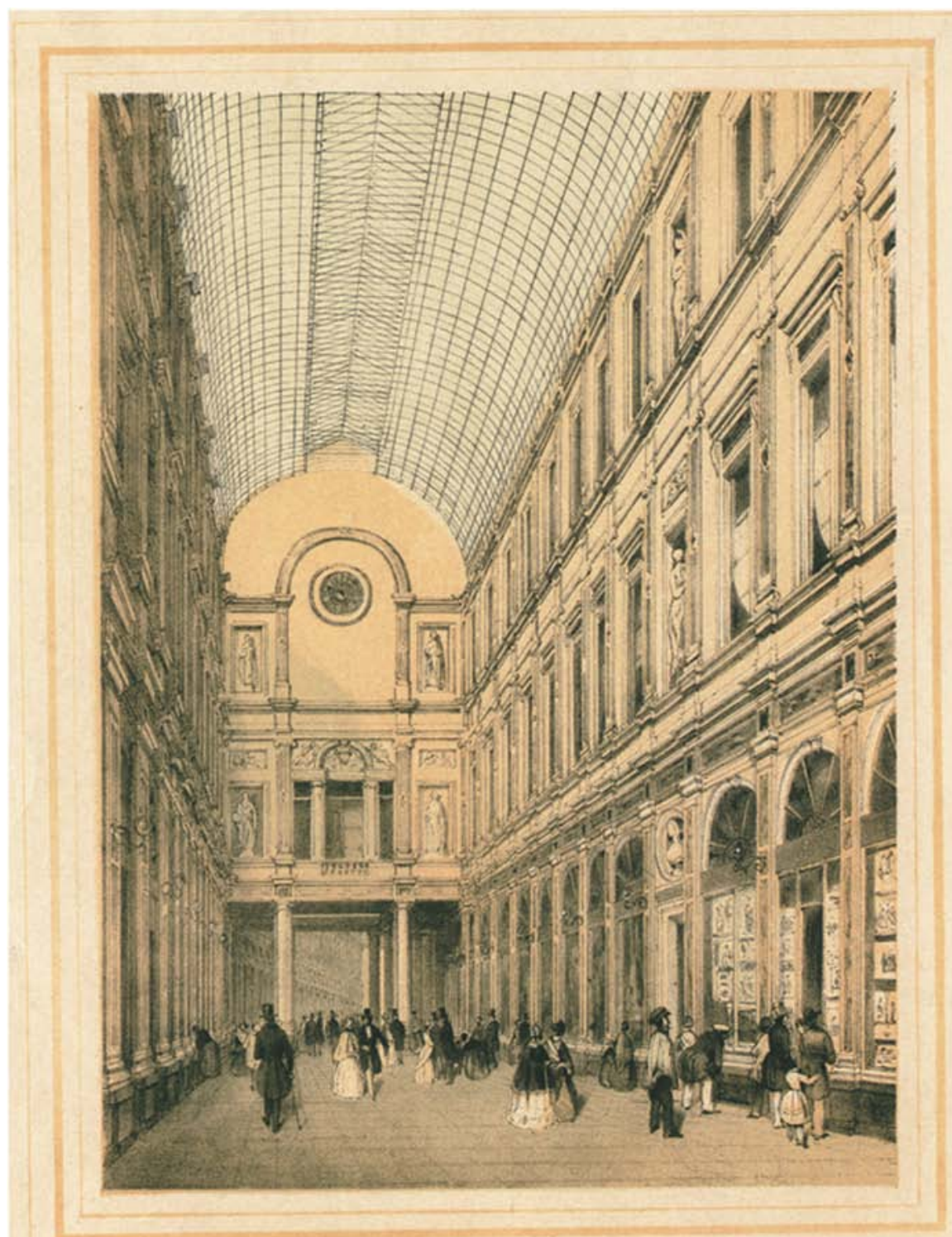

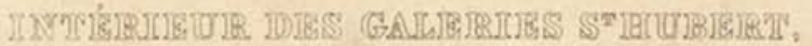
A BRUXFLLRS

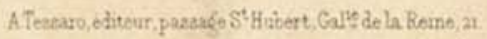




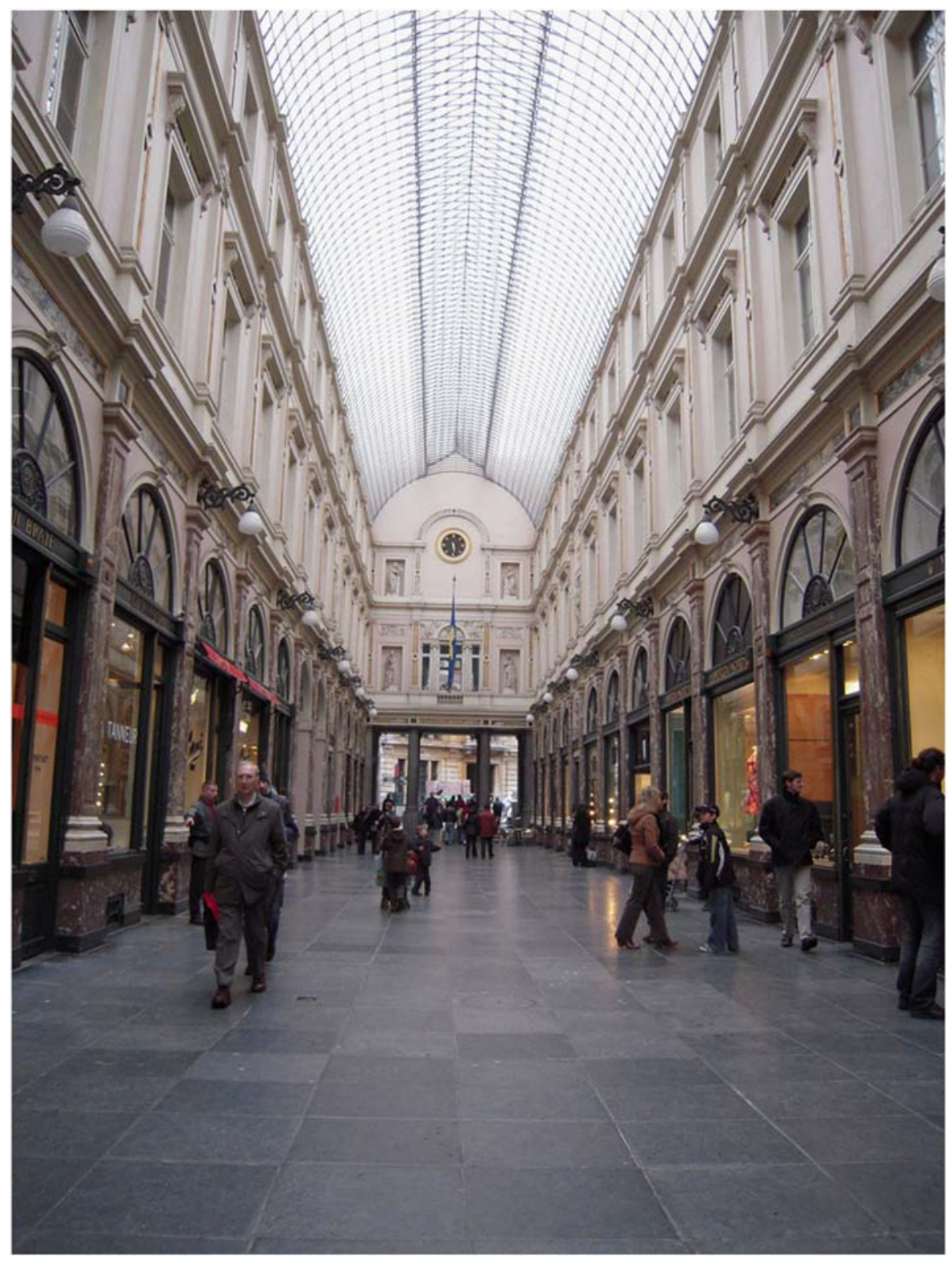

Shopping passages

Plate 3.

Galleries Saint-Hubert anno 2009

of the marbles used for flooring and decoration of the façades was set up and damaged elements were replaced by stones from the original quarry if possible. All new stones were carefully polished to match the original satin-like polish (RCMS, 1998). The original glazing of the glass roof has almost completely been replaced by new glazing at previous maintenance works. An aluminum stroke had been applied to 
JCHMSD

1,2 water tighten the structure, but this reduced the transmission of daylight. Now this aluminum stroke has been replaced by a water repellent joint to improve light transmission (Hellebois, 2006). A study of the original polychromy of the façades was made by consultation of old documents and archives, and by stratigraphic research. Experiments were done to expose the original paint layer, but this was too expensive and risky because the underlying paint may not everywhere been preserved in a good condition. Eventually, the original polychromy has been reconstructed on top of the existing paint layers (RCMS, 1998). Interior features such as the original gas lanterns, advertisement on the store fronts remained original. Some storefronts were slightly altered in the past. Their restoration was not part of the recent restoration project, probably because all stores remained open during the restoration. The advising reports in the archive of the RCMS show that after the 1997 restoration, many retailers restored their storefront on their own initiative. Currently, all store fronts have been restored.

On the other hand, the management of the Galleries Saint-Hubert made major efforts to preserve to intangible aspects such as its program, character and atmosphere. The rich diversity of activities - urban connection, dwelling, stores, bars, restaurants, a theater and a cinema - is preserved. Originally, depending on the required retail area, retailers could rent the shop entities separately or in a combination of maximum three. Shop owners could expand or reduce their area without leaving the passage. Also today the scale of the stores remained as intended by Cluysenaar; one to three bays wide. Retailers who require larger shop units can add the entresol to the commercial area. The luxurious character of the retail activity in the Galleries Saint-Hubert have grown historically (Société civile des Galleries royales Saint-Hubert, personal communication, February 25, 2009) and still today most stores sell luxury goods, some of them are specifically representing Belgian industries. Few stores' interiors have been preserved that date back to the nineteenth century (e.g. the Neuhaus store and a specialized store for gloves).

\subsection{The Galleria Vittorio Emanuele II in Milan}

History: The Galleria Vittorio Emanuele II (Plates 4 and 5) and most monumental example in the evolution of the passage (Geist, 1979). Its construction was an essential part of the monumental transformation of the historic center of Milan, transforming the Galleria into a political symbol for the city. An architectural competition was organized in 1862, with Giuseppe Mengoni (1829-1877) as laureate. Although the project initially was financed by private investors, the buildings were sold to the city of Milan shortly after they were completed in 1877.

The Galleria Vittorio Emanuele II is seven floors high - including the cellar and entresol - and both the interior and exterior are designed in a neoclassical style. The entrance at the Piazza del Duomo is marked by a triumphal arch, referring to classical Roman architecture and contrasting the gothic façade of the Duomo. The initial program was very elaborate including stores, bars, restaurants and exhibition rooms at the ground floor, club houses and offices at the entresol and apartments on the upper floors (Geist, 1979). An extensive photographic reportage is available on the construction and realization of the Galleria Vittorio Emanuele II (Flory and Paoli, 2003).

The buildings are largely preserved in their original state; only minor restoration works have been carried out in the past, such as the terrazzo flooring in the 1960's. Nevertheless, no documentation on this restoration works is available (The Urban Centre, personal communication, August 19, 2010). 


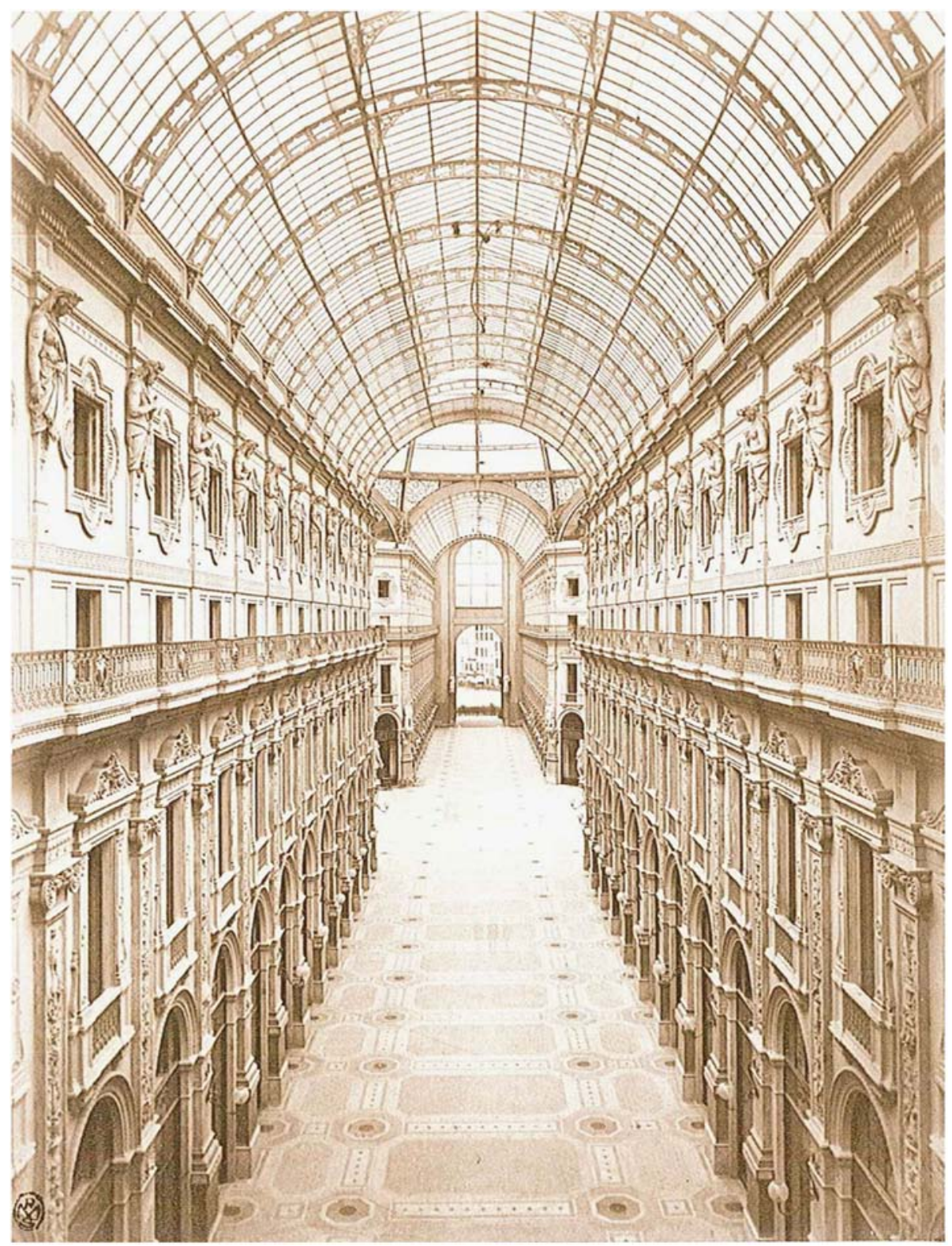

Shopping passages

145

Plate 4. Galleria Vittorio Emanuele II anno 1867 (Civico Archivio Fotografico, Milano)

Value assessment: The Galleria Vittorio Emanuele II represents the climax in the evolution of the passage as an architectural typology. As such, intrinsically the most important values are its monumental size and architecture as well as its program. Extrinsically, the building has been very well preserved and is still an important symbol for the city of Milan. 


\section{JCHMSD \\ 1,2}

146

\section{Plate 5.}

Galleria Vittorio

Emanuele II anno 2010

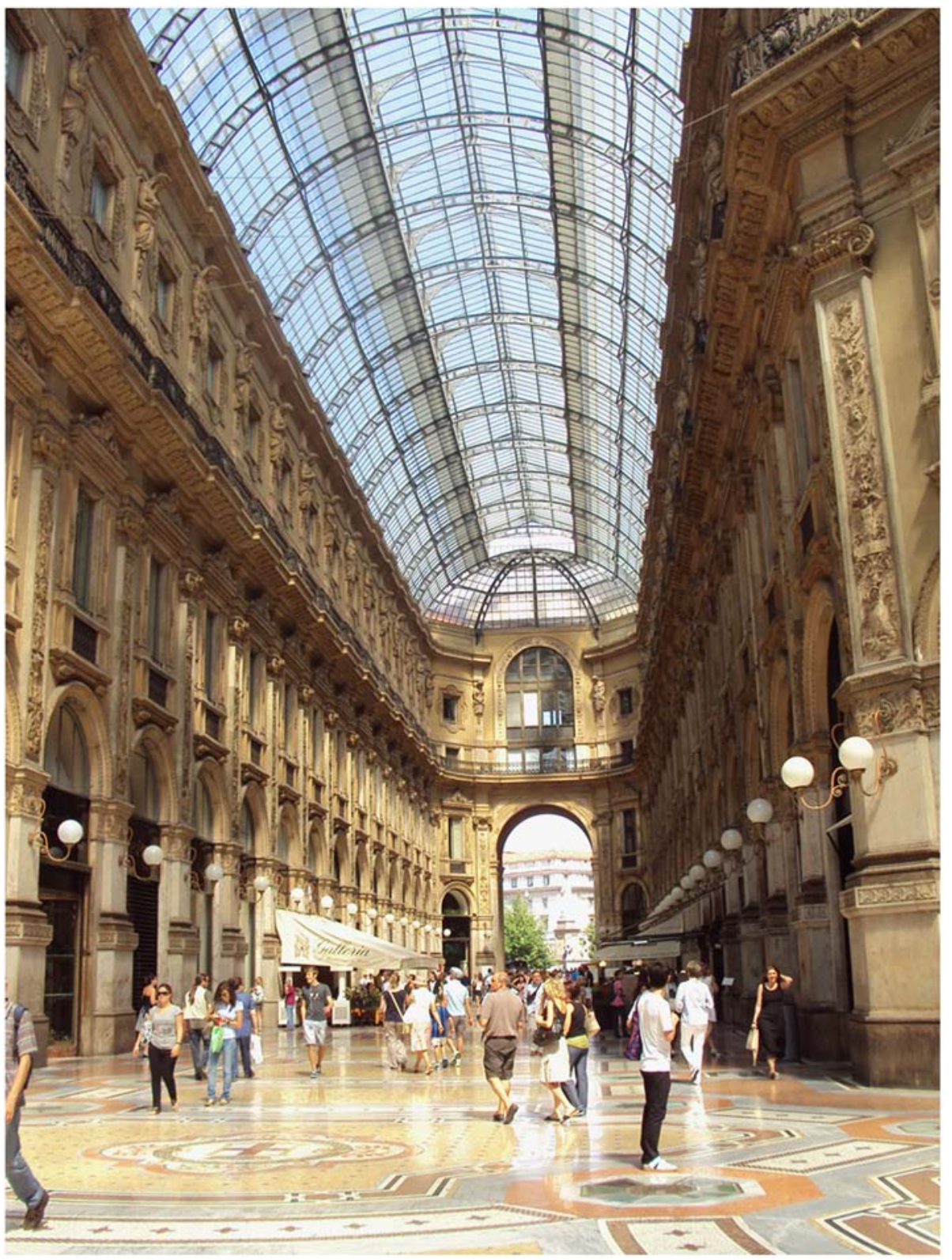

Conservation and management: The material architectural evidence of the Galleria Vittorio Emanuele II has been very well preserved such as the flooring, decoration, glass roof but also interior features such as the original store fronts, lanterns and statues are still present (Flory and Paoli, 2003).

Also the intangible aspects of the building have been preserved, although some of these aspects have changed in the course of history. The program of the building has 
slightly been altered; the upper floors, which initially housed apartments, are now transformed into a hotel and office spaces, some of which occupied by the municipality of Milan. On the ground floor near the Piazza della Scala, is the Urban Centre, used by the municipality to set up small exhibitions on urban development projects. This change in the buildings' program had hardly any architectural implication as no major transformations were made to the structure of the building; as such the change in use is completely reversible (Falcone, 2011).

The atmosphere of the building is preserved to a large extent. The Galleria Vittorio Emanuele II is still an attractive place for shopping and strolling. It includes many prestigious stores, some of which even with their original interiors, e.g. Prada store. Although, beside luxury stores, more popular restaurant chains, such as Mc Donalds, are equally present which may threaten the luxurious and exclusive character. However, the company logo and identity of Mc Donalds are adapted to the design of the store fronts by using only black and gold at the exterior. As such, it attracts less attention and does not interrupt the consistency of the passage. As in the Galleries Saint-Hubert, the stores are no more than three bays wide and some stores also occupy the entresol.

\subsection{The passage in The Hague}

History: During the second half of the nineteenth century, urban expansion of The Hague was necessary as it was one of the fastest growing cities in the Netherlands. In 1882, the assignment to design the Passage was given to architects Jan Christiaan van Wijk (1844-1891) and Herman Wesstra (1843-1911). The design of the building was characterized by an international eclectic style. At the start of the actual construction work, however, the available funds were insufficient to implement the existing plans. The architects made several suggestions to reduce the costs but these were all rejected. Instead, several financial institutions were approached to provide funds - but in vain, due to the difficult economic situation in the Netherlands. Finally, it was the Brusselsbased Caisse Hypothecaire who financed the project and consequently, appointed a Belgian contractor, Henri Mortiaux (Knibbeler, 1986). The architectural style of the realized building was not eclectic as initially proposed but neoclassical with a strong resemblance to the Galleries Saint-Hubert (Plates 6 and 7).

The building consisted of two galleries, four floors high; shops were located on the ground floor and apartments on the entresol and the upper floors. In the center of the Passage there was a hotel (Geist, 1979). The Passage was repaired and altered several times in the course of history. A third gallery was added in 1928-1929, following a design by architect Jos Duynstee in expressionistic style. The decorations on the upper floors of the two oldest galleries were removed in the 1960s (Knibbeler, 1986).

Over the decades, the Passage became fragmented property, and not all owners were equally motivated to maintain their property. The Passage gradually decayed. Today, it is owned by Fortis Bank who restored and rehabilitated the buildings for commercial purposes (S. Tol, personal communication, September 10, 2008). The scientific approach of its restoration, however, is debatable.

Value assessment: The most important values of the Passage are in its program and its function as an urban connection. Its architectural significance is only secondary as the original construction was already an alteration of the initial architectural concept (intrinsically). Moreover, the building had been altered several times in the course of history (extrinsically). 


\section{JCHMSD}

1,2

148

\section{Plate 6.}

Picture postcard 1904 (City Archive The Hague)

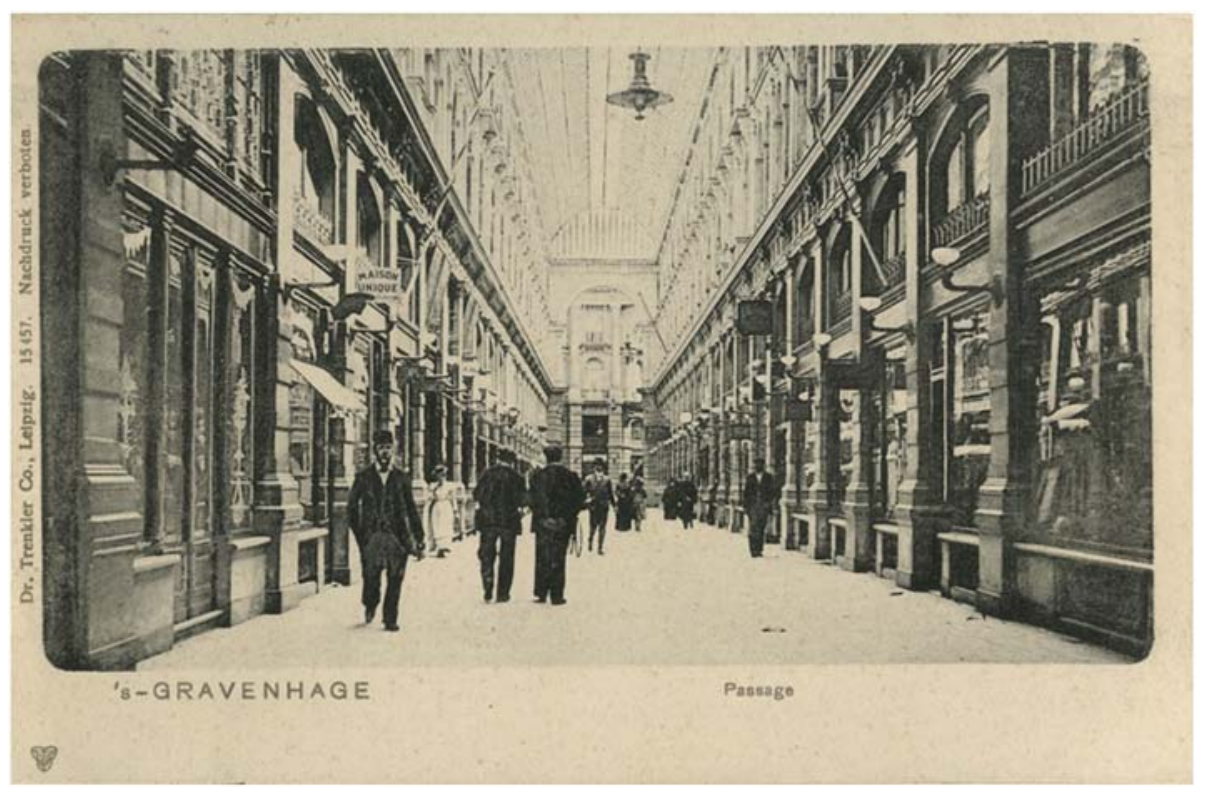

Conservation and management: The restoration of the Passage focussed on its functioning as an urban connection and aimed to restore the inner façades to its original condition. As such, the ornamentation that had been removed in the 1960's was reconstructed, based on historic photographs, and on few remaining ornaments in the rotunda that had been preserved and the terrazzo flooring was restored. However, the project lacked consistency as the reconstruction of material evidence was not done for all features. For example, there was no research to identify the original polychromy of the façades (R. de Booij, personal communication, March 10, 2010), although it would have been possible for some parts of the building. Instead, a contemporary polychromy was applied which had strong contrast between the different colors to accentuate the reconstructed decorations (S. Tol, personal communication, March 10, 2009). The original lanterns and advertisement has been replaced following a contemporary design.

The original program of the Passage, including shops, bars, private dwellings, a hotel and a theater, has not been preserved. Instead, the Passage is used primarily for commercial functions, being retail on the ground floor and offices on the upper floors. Consequently, alterations were made to accommodate the new activities, e.g. the interior of the apartments and the hotel have been removed and two bridges were constructed to connect both sides of the galleries on the first floor and the Passage is only accessible during business hours. There is a new hotel adjacent to the passage, but it is located in the former cinema and is oriented toward the street instead of the passage.

In the past all shops were only one bay wide; today several historic shops have been combined into one large shop unit to meet the needs of contemporary retailers for larger commercial areas. The former hotel and beer hall were transformed into large pilot stores. Because of this, the small-scale character of the initial retail function was lost. The shops that are today located in the Passage are generally selling more popular 


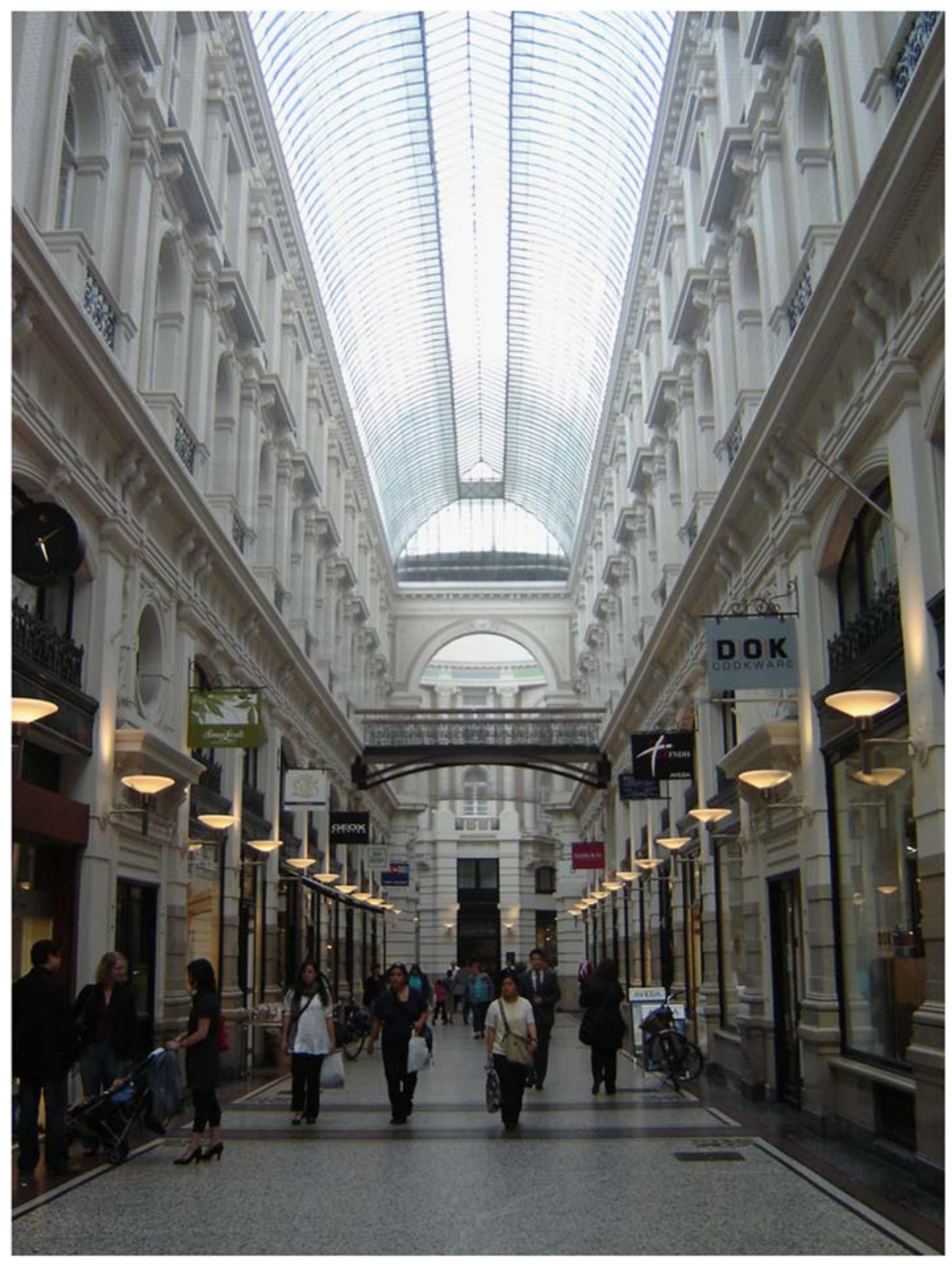

Shopping passages

Plate 7.

brands or even outlet stores, most of them furnished like any other store of the brand. As a result, the Passage failed to maintain its original grandeur and prestige, unlike Milan and Brussels.

Today the Passage connects two parts of the city with important retail activities. The character of both areas, however, is very different: the retail activity at the 
JCHMSD

1,2

150
Spuistraat is rather mainstream while the retail activity at the Buitenhof has a very exclusive character.

\subsection{Cross-case comparison}

Comparison between the cases illustrates the tensile area between heritage and retail development. On an architectural level, the Galleries Saint-Hubert and the Galleria Vittorio Emanuele II preserved well their original state (Figure 1). The Galleries Saint-Hubert is even an exemplary case of restoration of an historic monument without compromising on its authentic value; the Galleria Vittorio Emanuele II has not been restored as a whole so far but this will soon be inevitable. In the Passage, many adaptations have been made to the building over time and although the restoration project aimed to bring back the building to its original state, this has failed for a variety of reasons, but certainly for its weak restoration program and less prestigious contemporary retail program.

Initially, our three presented cases housed a rich variety of functions such as dwelling, shopping, bars and restaurants. In the Galleries Saint-Hubert the initial program is preserved entirely; only minor interventions in the interiors have been made to meet contemporary users' needs. In the Galleria Vittorio Emanuele II, the initial program has been adapted but still, there is an interesting mix of functions, including a role for the municipality. Only limited interventions have been made to enable the shift in use. In the Passage the initial program is not preserved and all functions are solely focussed on revenue - stores and offices - and therefore major architectural interventions were made.

We also compared the retail activity in the three passages. In the Galleries SaintHubert and Galleria Vittorio Emanuele II the shops maintained their original size, and if a retailer feels the need to enlarge the store the entresol could be added to the commercial space. The passage stores in Brussels and Milan are selling luxury goods, several of them even in well preserved nineteenth century interiors (e.g. Neuheus in Brussels and Prada in Milan). Especially in the Galleria Vittorio Emanuele II the stores are mainly exclusive. The stores in the Passage are selling average goods and are occupied by more popular retailers. The tenants here are free to rent several store

Figure 1. Site plans
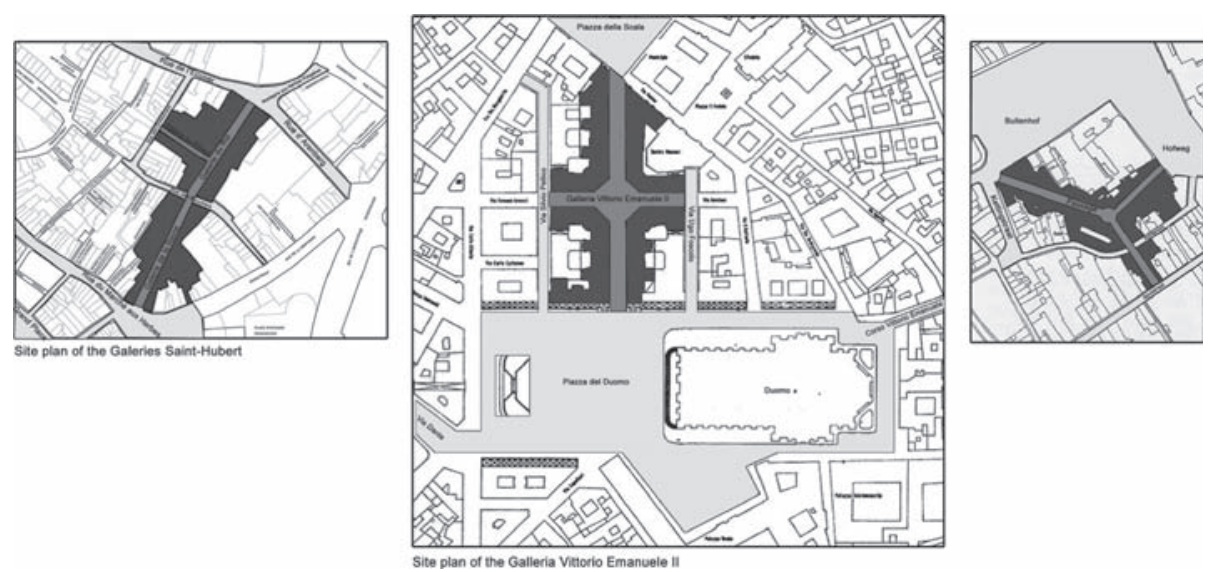

Source: Geist, 1979 adapted by the author 
entities which can be combined to a large store. As such, the small scale retail activity that has been typical for the passages is not preserved.

The Galleries Saint-Hubert and Galleria Vittorio Emanuele are still frequently used by locals and tourists as an urban connection. The Passage, although initially intended as a necessary connection within the urban fabric, is not used that frequently as a passage way as it connects two parts of the city which currently have a completely different character. Moreover the Passage is only accessible during business which limits its urban function.

The difference in quality of conservation and management between the projects did, however, not arise in recent years but has grown historically. Although all three passages are legally protected as a monument by their own national state, the motivation for preserving the authentic value of the building was not the same for each case. In the case of the Passage a loss of the heritage value could not be avoided due to commercial pressure. In the Galleria Vittorio Emanuele II, the changes in program have not caused a loss of authenticity so far but still, when conducting an overall restoration of the building in the future pressure for commercial development could cause a threat toward the preservation of the value of the site (Figure 2).

\section{Conclusion}

In the Galleries Saint-Hubert, the restoration program and the site management focuses on preserving the site as an historic monument, emphasizing its historic and architectural values but also the intangible values such as the buildings' character and atmosphere.

The Galleria Vittorio Emanuele II is - still - managed as a symbol of the city of Milan, especially since the presence of several official functions such as the municipality offices and The Urban Centre. This also links its program to the original characteristic as political symbol in the context of national identity and possible also as a profane statement against the Gothic façade of the cathedral. However, commercialization of the site, e.g. introduction of chain restaurants with standardized interiors, may become a threat in the future. Although the changes in program did not influence the tangible values of the buildings (the architecture), it may harm its intangible values (character and atmosphere).

Management of the Passage was primarily commercially driven which influenced strongly its tangible and intangible values. In Milan, we mentioned the conservation of quality and consistency despite functional changes. The Hague, on the other hand failed to reconstruct this atmosphere because its program and restoration lacked sophistication, subtility and consistency.

Some lessons may be learned from the case studies that can be applied to passages in general. First, the cases show the importance of combining diverse activities on the site, commercial (e.g. shops, bars, restaurants and offices) and non-commercial (e.g. dwelling, culture). Second, the selection of retailers seem to determine the atmosphere; retailers located in a passage need to consider the restrictions due to building's characteristics. Large-scale retail activities and standardized interiors should be avoided. Third, the historic symbolic value of the passage (political, cultural, social and economic) should be respected although it may be reinterpreted in relation to contemporary society. Fourth, the relation with the historic fabric needs to be preserved. In the case of World Heritage, indicating a buffer zone around the site may be an answer.

To conclude, the authentic value of passages as a building type is not limited to its architecture - the material evidence - but equally concerns the buildings' program 


\section{JCHMSD \\ 1,2}

152

Figure 2.

Matrix illustrating the cross-case-comparison between the case studies $\square$ authentic value has been preserved; $\square$ authentic value has not been preserved; $\square$ authentic value is threatened; $\square$ no sufficient data available

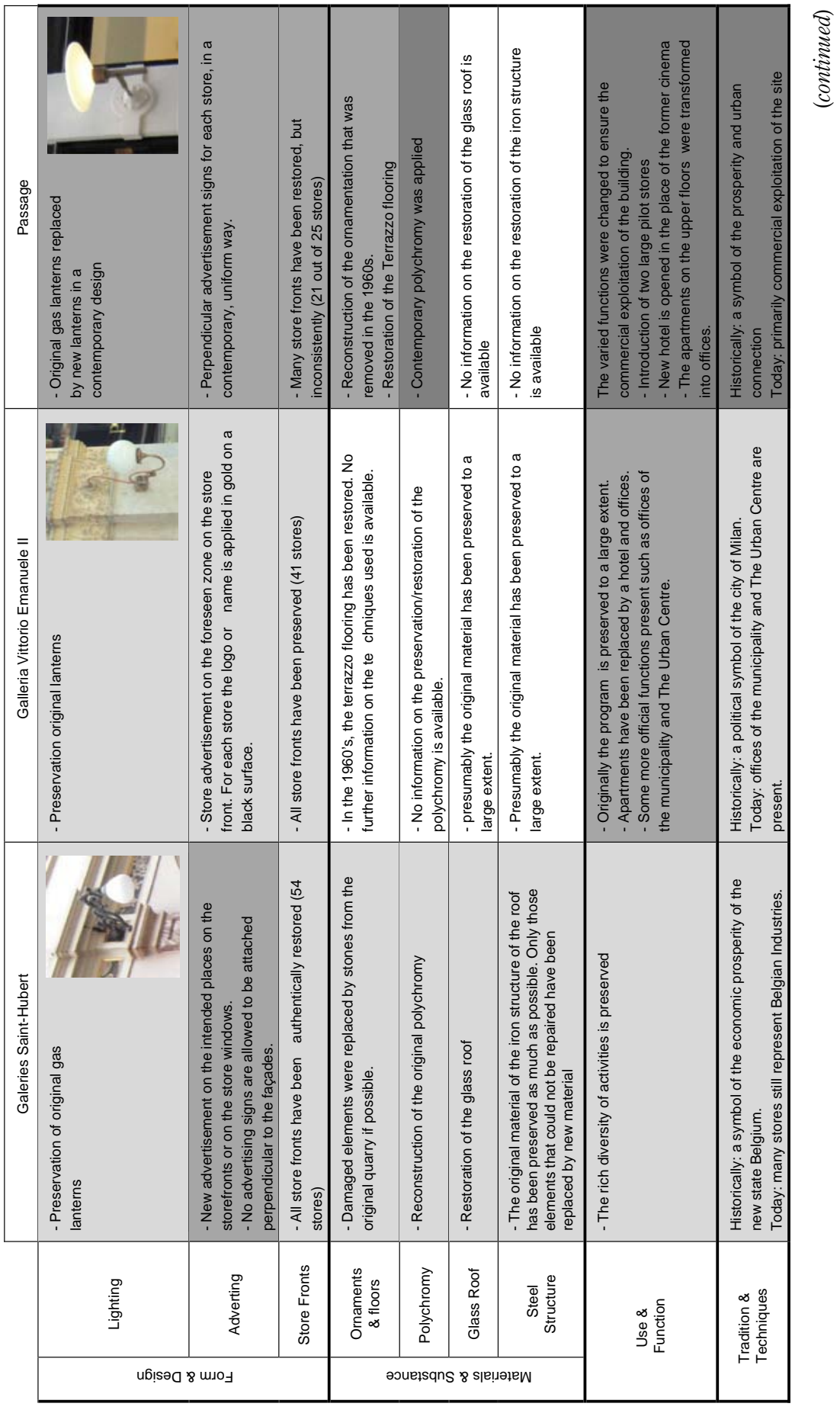




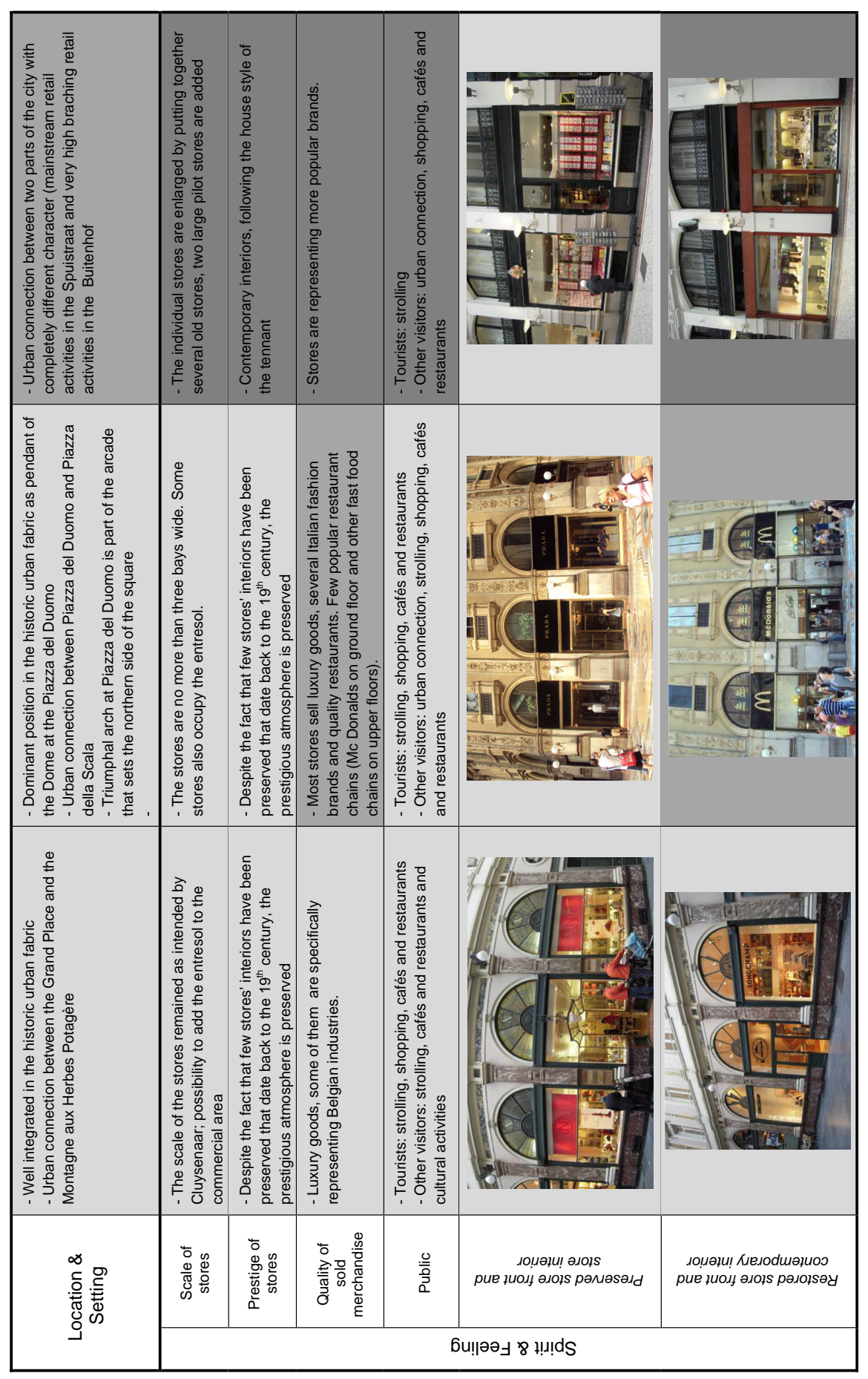

Shopping passages

153

Figure 2. 
JCHMSD

1,2

154 which includes a mix of contemporary functions - the intangible aspects. This mix of functions had always been the key to their success. As such, Galleries Saint-Hubert can be considered as exemplary for other projects both on the level of restoration as to contemporary management. Already in the nineteenth century this Galleries inspired designers all over Europe in the development of a passage, today this building can perhaps again inspire the conservation of this exceptional building type in historic city centers in Europe.

\section{Implications}

Within the scope of this research we have selected three case studies through critical case selection. Nevertheless, many other passages in Europe and beyond would be worth assessing; Geist (1979) made an exhaustive inventory including 275 passages in Europe out of which 151 did still exist. If UNESCO would consider a transnational inclusion of passages in the World Heritage List, it could be beneficial to make a selection of exemplary cases across Europe. This selection should be based not only on the historical, architectural and urban significance of the building but also on the quality of its contemporary preservation, taking into account tangible as well as intangible values. The matrix presented in this paper may be used as a tool for nominating those passages worth listing as World Heritage site and may be useful in formulating guidance for conservation treatment and site management of (the nominated) passages to obtain a well-balanced mix between heritage conservation and contemporary (commercial) exploitation of the site. Moreover, because of its straightforward representation the matrix may easily be used by an (interdisciplinary) group of experts discussing and collaboration on one project.

Beside implications toward the nomination, conservation and management of passages, the methodology may be found useful for assessing other types of heritage which authenticity is threatened by uncontrolled retail development, World Heritage sites but also heritage with national or local significance.

\section{References}

Assi, E. (2000), "Searching for the concept of authenticity: implementation guidelines", Journal of Architectural Conservation, Vol. 3 No. 3, pp. 60-9.

Benjamin, W. (1969[1935]), “Capital of the nineteenth century”, Perspecta, Vol. 12 No. 1, pp. 163-72.

Benjamin, W., Tiedemann, R. and McLaughlin, K. (2002[1932]), The Arcades Project, Harvard University Press, Harvard, MA.

Cameron, C. (2006), "Conservation in changing societies: world heritage indicators", in Patricio, T., Van Balen, K. and De Jonge, C. (Eds), Conservation in Changing Societies. Heritage and Development, Raymond Lemaire International Centre for Conservation, Leuven, pp. 39-47.

Conde Reis, G. (1998), "Geschiedenis en architectuur. Bijdrage tot een analyse", in RCMS (Ed.), De Sint-Hubertusgalerijen. Gechiedenis \& restauratie, Dienst Monumenten en Lanschappen van het Brussels Hoofdstedelijk Gewest, Brussels, pp. 13-63.

Davis, D. (1966), A History of Shopping, Routledge \& Kegan Paul Ltd: University of Toronto Press, London.

Davison, G. (2008), "Heritage, from patrimony to pastiche”, in Fairclough, G., Harrison, R., Jameson, J. and Schofield, J. (Eds), The Heritage Reader, Routledge, New York, NY, pp. 31-41.

English Heritage, English Historic Towns Forum, \& Planning Advisory Service (2005), Retail Development in Historic Areas, English Heritage, London. 
Falcone, R. (2011), "De Passage, vernieuwing van een hedendaagse publieke ruimte", Master thesis, Department of Arts and Architecture, PHL University College, Diepenbeek.

Flory, M. and Paoli, S. (Eds) (2003), La Galleria di Milano. Lo spazio e l'immagine, Skira, Milano.

Geist, J. (1979), Passagen: ein Bautyp des 19. Jahrhunderts, Prestel-Verlag, Munchen.

Grayson, K. and Martinec, R. (2004), "Consumer perceptions of iconicity and indexicality and their influence on assessment of authentic market offerings", Journal of Consumer Research, Vol. 31 No. 2, pp. 296-312.

Hellebois, A. (2006), "Les Galeries Saint-Hubert. Une réalisation emblématique du 19ième siècle. Techniques de construction et de renovation", working paper, Faculté des Sciences Appliquées, Université Libre de Bruxelles, Bruxelles.

Heynen, H. (2006), “Questioning authenticity”, National Identities, Vol. 8 No. 3, pp. 287-300.

ICOMOS (1964), "The Venice Charter. International charter for the conservation and restoration of monuments and sites", Venice, May 25-31.

ICOMOS (1994), "The Nara document on authenticity in relation to the World Heritage Convention”, Nara, November 1-6.

Jokilehto, J. (1985), “Authenticity in Restoration Principles and Practices”, Bulletin of the Association for Preservation Technology, Vol. 17 Nos 3/4, pp. 5-11.

Jokilehto, J. (1999), A History of Architectural Conservation, 4th ed., Elsevier, Oxford.

Knibbeler, T. (1986), “De Haagse Winkelpassage (1882-1885)”, unpublished thesis, Radboud Universiteit Nijmegen.

Kooijman, D. (1999), Machine en theater. Ontwerpconcepten van winkelgebouwen, 010, Rotterdam.

Larsen, K. (Ed.) (1995), NARA conference on authenticity in relation to the World Heritage on authenticity in relation to the World Heritage/Conference de NARA sur l'authenticite dans le cadre de la Convention du patrimoine Mondial, UNESCO World Heritage Centre, Paris.

Lemoine, B. (1990), Les passages couverts en France, Délégation à l'action artistique de la ville de Paris, Paris.

MacKeith, M. (1986), The History and Conservation of Shopping Arcades, Mansell Publishing Limited, London and New York, NY.

Mason, R. (2002), "Assessing values in conservation planning: methodological issues and choices", in de la Torre, M. (Ed.), Assessing the Values of Cultural Heritage, Getty Conservation Institute, Los Angeles, CA, pp. 5-30.

Mesher, L. (2010), Retail Design, AVA Publishing, Lausanne.

Miellet, R. (2001), Winkelen in weelden. Warenhuizen in West-Europa 1860-2000, Walburg Pers, Zutphen.

Muñoz Viñas, S. (2005), Contemporary Theory of Conservation, Elsevier, Amsterdam.

Pedersen, A. (2002), Managing Tourism at World Heritage Sites: a Practical Manual for World Heritage Site Managers, UNESCO World Heritage Centre, Paris.

Pevsner, N. (1976), A History of Building Types, Princeton University Press, Princeton, NJ.

Plevoets, B., Petermans, A. and Van Cleempoel, K. (2010), "Developing a theoretical framework for understanding (staged) authentic retail concepts in relation to the current experience economy", paper presented at the DRS2010, Montreal, July 7-9.

Plevoets, B. and Van Cleempoel, K. (2009), "Retail-reuse of historic buildings: developing guidelines for designer and conservators", WTA Schriftenreihe. Building Materials and Building Technology to Preserve the Built Heritage, Vol. 33 No. 1, pp. 61-80. 
JCHMSD

1,2
Royal Commission of Monuments and Sites of the Brussels Capital Region (RCMS) (1998), de SINT-HUBERTUSgalerijen. geschiedenis \& restauratie, Royal Commission of Monuments and Sites of the Brussels Capital Region, Brussels.

Smith, L. (2006), Uses of Heritage, Routledge, London \& New York, NY.

Starn, R. (2002), "Authenticity and historic preservation: towards an authentic history", History of the Human Sciences, Vol. 15 No. 1, pp. 1-16.

Stovel, H. (2007), "Effective use of authenticity and integrity as world heritage qualifying conditions", City \& Time, Vol. 2 No. 3, pp. 21-36.

Timothy, D. and Boyd, S. (2003), Heritage Tourism, Prentice Hall, Harlow.

UNESCO (1977), “Operational Guidelines for the World Heritage Committee”, Paris, June 27-July 1.

UNESCO (2008a), Operational Guidelines for the Implementation of the World Heritage Convention, UNESCO, Paris.

UNESCO (2008b), "World heritage tentative list”, available at: http://whc.unesco.org/en/ tentativelists/5355/ (accessed February 25, 2009).

UNESCO (2010), “About world heritage”, available at: http://whc.unesco.org/en/about/ (accessed September 6, 2010).

Van Balen, K. (2008), "The Nara grid: an evaluation scheme based on the Nara document on authenticity", Association for Preservation Technology International (APT Bulletin) Special Issue, Vol. 39 Nos 2/3, pp. 39-45.

Vanderburgh, D. and Du Four, G. (1999), "Brussels and the arcades of (the) capital", Parallax, Vol. 5 No. 3, pp. 9-21.

Yin, K. (2009), Case Study Research. Design and Method, Sage, Los Angeles, CA, London, New Delhi, Singapore and Washington, DC.

Zeisel, J. (2006), Inquiry by Design, W.W. Norton \& Company, New York, NY and London.

\section{About the authors}

Bie Plevoets studied Interior Architecture at the PHL University College in Hasselt (BE) and her Master's thesis was entitled "Re-use of convents: a social and architectural challenge", reflecting her interest in heritage conservation. She followed a postgraduate Master in Conservation of Monuments and Sites at the Raymond Lemaire International Centre for Conservation (Catholic University Leuven). Currently she is working on a PhD research at the PHL University College and Hasselt University, dealing with the tension between heritage and retail in historic city centres in Europe. Bie Plevoets is the corresponding author and can be contacted at: bie.plevoets@phl.be

Koenraad Van Cleempoel studied Art History in Louvain, Madrid and London, where he obtained his $\mathrm{PhD}$ degree at the Warburg Institute. Since 2005 he has been engaged in establishing and directing a research unit in interior architecture at PHL University College. He is the supervisor of four $\mathrm{PhD}$ students on subjects of retail design and domesticity. Previously he has published on the relationship between art and science during the renaissance period, especially in the field of scientific instruments; but currently he has shifted his attention to the modernist period, looking at polychromic interiors of Le Corbusier and De Stijl and trying to understand its influence on Belgian modernists. Another area of research is the presence of the occult in the discourse of several modernist artists, Mondrian in particular.

To purchase reprints of this article please e-mail: reprints@emeraldinsight.com Or visit our web site for further details: www.emeraldinsight.com/reprints 